Reprod. Nutr. Dévelop., 1988, 28 (4 B), 1145-1164

\title{
Recent data on the structure of rabbit milk protein genes and on the mechanism of the hormonal control of their expression
}

Eve DEVINOY, Christine HUBERT ( ${ }^{1}$ ), Geneviève JOLIVET, D. THEPOT, Nadine CLERGUE, Martine DESALEUX, M. DION, J.-L. SERVELY, L. - M. HOUDEBINE ( ${ }^{2}$ )

Unité de Différenciation cel/ulaire, I.N.R.A., 78350 Jouy-en-Josas, France.

Summary. Mammary explants or isolated mammary cells from rabbit have been cultured in the presence of insulin, prolactin and cortisol alone or in combination. The cellular content in $\alpha_{\mathrm{s} 1}$-casein, $\beta$-casein and whey acidic protein (WAP) mRNA have been evaluated using the corresponding cDNA as probes. In all cases $\alpha_{\mathrm{s} 1}$-casein mRNA was the most abundant and WAP mRNA the least abundant mRNA. The three genes showed essentially similar dependency towards hormones. Prolactin stimulated mRNA accumulation and insulin and cortisol amplified this stimulation. The induction by prolactin was rapid whereas stimulation by insulin was slower. Fragments of rabbit genomic DNA inserted in $\lambda$ phage and containing $\alpha_{\mathrm{s} 1}$-casein, $\beta$-casein and WAP genes have been cloned. The primary sequence around the CAP site of the three genes has been established. A comparison of the sequences located upstream from the CAP site shows several striking homologies with the corresponding genes from cow, rat and guinea-pig. This suggests that these sequences participate in the transcriptional control of the genes by hormones. The mechanism involved in the transduction of the prolactin message to milk protein genes in unknown. Using mammary explants in culture, several classical mechanisms of transduction have been examined. Phorbol ester, phorbol -12, 13-dibutyrate (PdiBu) inhibited prolactin action. However, another tumor promoter, 12-0-tetradecanoyl phorbol -13-acetate (TPA), did not alter prolactin action. Kinase $\mathrm{C}$ inhibitor $\mathrm{H} 7$ did not prevent prolactin action and did not overcome the inhibition by PdiBu. Kinase $\mathrm{C}$ is therefore not essential for the transduction of the prolactin message to milk protein gene. Neomycin, which inhibits phosphatidylinositol hydrolysis by phosphorylase $\mathrm{C}$, prevented prolactin action, whereas other inhibitors of phosphatidylinositol metabolism remained uneffective. Degradation of phosphatidylinositol is therefore likely not an essential step of prolactin action on milk protein genes. Inhibitors of tyrosine kinase and phosphatase exhibited a poor capacity to modify the prolactin response. Hence, transduction mechanisms using tyrosine kinase activity likely cannot account for prolactin action.

\section{Introduction.}

Milk protein synthesis is under the control of several hormones. In the rabbit, freshly explanted mammary tissue is sensitive to prolactin alone whereas insulin

( $\left.{ }^{1}\right)$ Present address : U. 36-INSERM, 17, rue du Fer-à-Moulin, 75005 Paris, France.

( $\left.{ }^{2}\right)$ To whom correspondance should be addressed. 
and glucocorticoids greatly enhance in an independant manner the accumulation of $\beta$-casein mRNA (Houdebine et al., 1985). Progesterone in vivo (Teyssot and Houdebine, 1980) and in vitro (Jahn et al., unpublished results) inhibits prolactin action. Prolactin receptor has been isolated and characterized. Polyclonal and some monoclonal antibodies raised against the receptor can mimic prolactin actions (Djiane et al., 1981, 1985). The hormone is therefore not necessary beyond its receptor, and a mediator of unknown nature must be generated at the membrane level (Houdebine et al., 1985). In order to elucidate the essential steps of the mechanism of prolactin action on milk protein gene expression, a study of the hormonal receptor at the molecular level and of several prolactin target genes have been undertaken. The data reported in the present paper are related to the structure and the hormonal control of three rabbit milk protein genes. Experiments carried out in many different biological systems have shown that the essential regulatory elements for transcription are located in the upstream region of the genes (Maniatis et al., 1987). For that reason, the structure of the regions upstream from the CAP site of rabbit $\alpha_{\mathrm{s} 1}$-casein, $\beta$-casein and WAP genes have been determined and compared to homologous genes of other species. Several experiments aimed at determining the possible transduction mechanism of the prolactin message to milk protein genes are also reported.

\section{Results.}

\section{Hormonal control of the expression of rabbit milk protein genes.}

Previous studies have shown that in the rabbit, $\beta$-casein gene expression is triggered by prolactin in cultured mammary explants and that this action is amplified markedly by insulin and cortisol (Houdebine et al., 1985). Results of figure 1 indicate that the same is true for two other rabbit milk protein genes, $\alpha_{\mathrm{s} 1}$-casein and whey acidic protein (WAP) genes. In all cases, in vivo and in vitro, $\alpha_{\mathrm{s} 1}$-casein was the most and WAP the least abundant of the three mRNAs. Interestingly, isolated rabbit epithelial mammary cells cultured on floating collagen exhibited essentially a similar sensitivity towards the three hormones (fig. 2). In this respect, rabbit appears different from mouse in which WAP gene is expressed in cultured explants but no more in isolated cells (Lee et al., 1985).

Mammary explants cultured for two days in the presence of insulin and cortisol kept an excellent sensitivity towards prolactin which triggered a rapid accumulation of $\beta$-casein mRNA (fig. 3). As opposed, tissue cultured for two days in the absence of hormone had lost a large part of its capacity to respond to the prolactin stimulation (not shown). The mammary explants cultured for two days in the presence of only prolactin could be stimulated by insulin for the accumulation of $\beta$-casein but this stimulation took place relatively slowly (fig. 4). Insulin is known to stimulate or inhibit specific gene expression and its action is slow in some cases (Flaim et al., 1985) and rapid in others (Lee et al., 1986). Insulin action on casein gene belongs rather to the first category. 


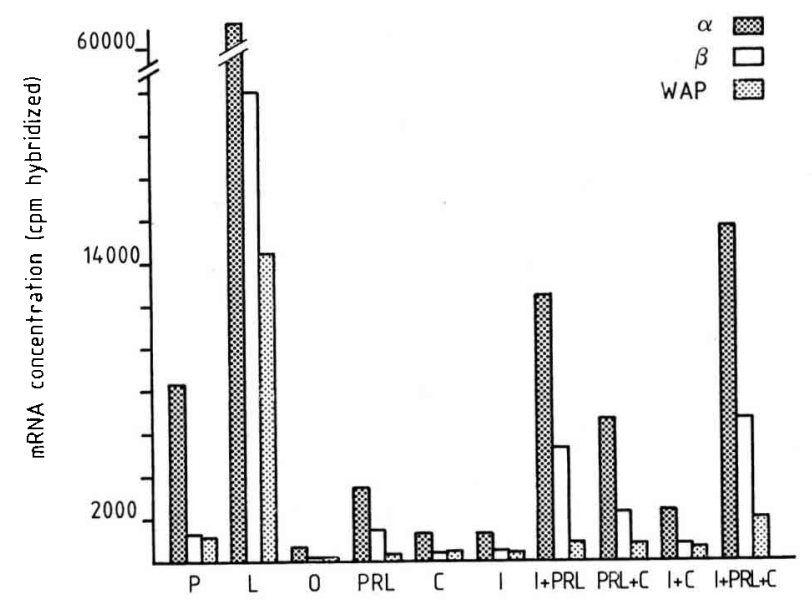

FIG. 1. A. - Effect of hormones on the induction of $\alpha_{s 1}$-casein, $\beta$-casein and WAP mRNA in mammary explants. Rabbit mammary fragments explanted at day 13 of pregnancy were cultured for 48 hours in the presence of insulin $(1: 5 \mu \mathrm{g} / \mathrm{ml})$, cortisol $(\mathrm{c}: 500 \mathrm{ng} / \mathrm{ml})$ and prolactin $(\mathrm{PRL}: 1 \mu \mathrm{g} / \mathrm{ml})$ as mentioned on the figure. Three cultures were performed independently. Total RNA was extracted from explants in each case and equal amounts of RNA of each hormonal treatment resulting from the three cultures were mixed. RNA $(10 \mu \mathrm{g})$ was bound to nitrocellulose filters and hybridized separately with the three cDNA probes $\left(10^{8} \mathrm{cpm} / \mu \mathrm{g}\right.$ DNA in each case $)$. Results which are the means of triplicates are expressed as cpm of the cDNA probe specifically hybridized to filters. $P$ and $L$ designate pregnancy and lactation respectively. Hybridization was then carried out with RNA isolated from fresh tissue.

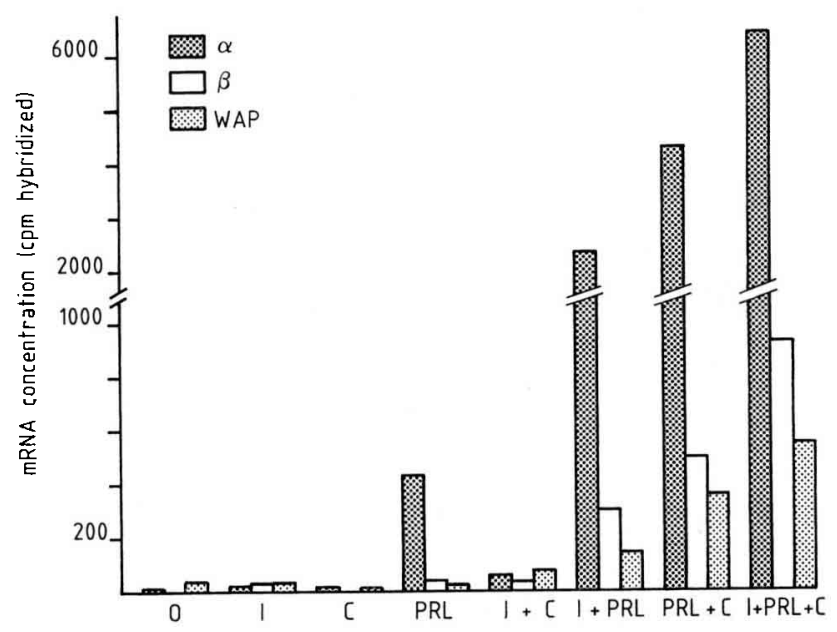

FIG. 2. - Effect of hormones on the induction of $\alpha_{s 1}$-casein, $\beta$-casein and WAP gene in isolated cultured mammary cel/s. Cells were cultured on floating collagen as previously described (Servely et al., 1987). About $5 \times 10^{6}$ cells were present in each dish. The whole RNA was bound to nitrocellulose filters and hybridized to labelled cDNA probes (the three probes had not the same specific activity). Results which are the mean of triplicates are expressed as cpm of the probe specifically hybridized to filters. 


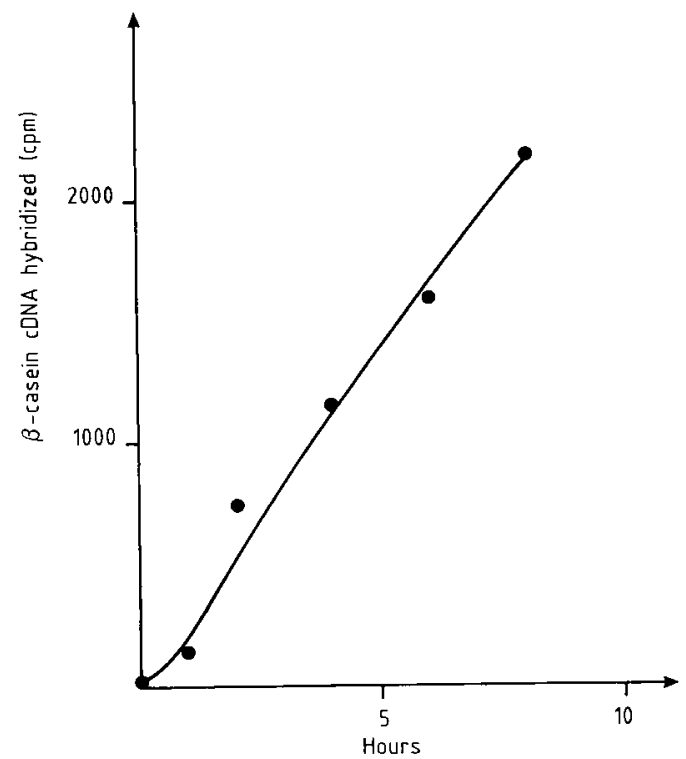

FIG. 3. - Kinetic of induction of $\beta$-casein mRNA accumulation by prolactin. Mammary explants from mid-pregnant rabbit cultured for two days in the presence of insulin $(5 \mu \mathrm{g} / \mathrm{ml})$ and cortisol $(500 \mathrm{ng} / \mathrm{ml})$. Prolactin $(1 \mu \mathrm{g} / \mathrm{ml})$ was then added to the culture medium. Culture of explants was stopped at different times after the addition of prolactin. The presence of $\beta$-casein mRNA was evaluated with a specific cDNA probe as depicted in fig 1.

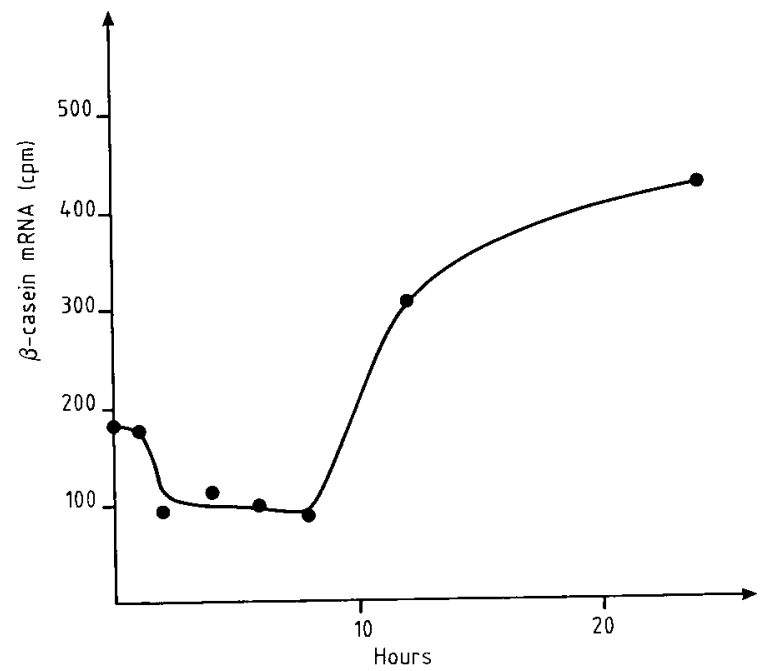

FIG. 4. - Kinetic of induction of $\beta$-casein mRNA accumulation by insulin. Mammary explants from mid-pregnant rabbit cultured for two days in the presence of prolactin alone $(100 \mathrm{ng} / \mathrm{ml})$. Insulin $(5 \mu \mathrm{g} / \mathrm{ml})$ was then added and $\beta$-casein mRNA was measured at different times after the addition of insulin as depicted in fig. 1. 


\section{Determination of the structure of the upstream regions of three rabbit milk protein genes.}

Experiments carried out several years ago in different laboratories have shown that the expression of milk protein genes is regulated at the transcriptional level by prolactin, insulin and glucocorticoids and that the half-life of the corresponding mRNA is greatly enhanced by prolactin and glucocorticoids (Houdebine et al., 1978; Guyette et al., 1979 ; Ganguly et al., 1979 ; Teyssot and Houdebine, 1980 ; Chomczynski et al., 1984, 1986). Signals controlling milk protein gene transcription are expected to be located in the upstream region of their CAP sites whereas other signals controlling mRNA stability are expected to be present in the mature mRNA. Recent experiments using mouse WAP gene regulatory sequences fused to ras oncogene and to plasminogen activator gene have shown that the WAP gene sequences are able to selectively direct the expression of the foreign genes in the mammary gland, although at a limited rate (Andres et al., 1987; Gordon et al., 1987). On the contrary, the whole sheep $\beta$-lactoglobulin gene was expressed with high efficiency in the mammary gland of transgenic lactating mouse (Simons et al., 1987). To address this problem, the cDNAs for rabbit $\alpha_{\mathrm{s} 1}$-casein, $\beta$-casein and WAP have been cloned (Suard et al., 1982; our laboratory, unpublished results) and sequenced (results to be published elsewhere). These CDNAs have been used as probes to select $\lambda$ phages, harbouring the corresponding genomic DNA, from a genomic library prepared in T. Maniatis' laboratory (Maniatis, 1978).

1) Characterization of the clones. - One clone isolated, using the $\alpha_{\mathrm{s} 1}$-casein cDNA as probe, harboured a $12 \mathrm{~Kb}$ fragment of genomic DNA which contains the 5 'half of the corresponding mRNA (450 bp) and $10 \mathrm{~Kb}$ upstream from the CAP site.

The clone having $\beta$-casein sequence contained, in $11 \mathrm{~Kb}$, the entire gene encoding this milk protein mRNA ( $1200 \mathrm{bp}$ ). This clone also contained $320 \mathrm{bp}$ in the upstream region of the CAP site.

One of the clones harbouring the WAP CDNA sequence contained about half of the WAP mRNA sequence ( $260 \mathrm{bp}$ ) and $17 \mathrm{~Kb}$ in the upstream region of the CAP site.

Classical genetic studies (Grosclaude et al., 1978) and kinetics of hybridization of cDNA with whole genomic DNA (Houdebine, 1977) have shown that essentially one copy of each casein gene is present per haploid genome. This fact was later confirmed for rat WAP, $\alpha_{\mathrm{s} 1}$-casein and $\beta$-casein genes using southern blotting (Campbell et Rosen, 1984 ; Jones et al., 1985, Yu-Lee et al., 1986). The same was observed for rabbit $\beta$-casein gene (unpublished result).

In the three genomic fragments we have isolated and described above, sequences of the corresponding cDNA were found. Therefore, these isolated genomic DNAs are fragments of the single $\alpha$-casein, $\beta$-casein and WAP genes expressed in the mammary gland.

2) Sequence of the upstream regions of the three genes. - Results of figures 5,6 and 7 indicate that the three genes have a TATA box located at the expected position, i.e. between -24 and -30 bp from their CAP site. $\beta$-casein gene 
A.

gaat tet tagaatttaaataaacctat tggttgatctgaaacc 2

acaaaat tagcatt tactgatcactgggtt aaatact tgtgaagcaaagagatcgacc $=$

ATCGCCTAGATCATCAACCCAACTTGCCTCTTTTCAGTCGAGTTTAAG gtattg

gtgatcaaatcatacgatt cacactgtctaatgtcttcttctgcttttat taagatg

tatt tgtaactttctatgttggaaatgtgataccttttaagatatactggtagctt

aaatgcatt tcaaatt taatactatctcagagett taggtaagaaatgtatatggc

at tataagaccaadcattettgct taatgtgtaactatatctcatacact tatcact

atct tcaatagaaact tagaataaggtaat tgaat tct t tagcccaat tctatgaaa

ttattgtgaaaataat tactatcttgcaattgctatagcaaggettgtt tggtag

aatattcaagactcagtt tattccatatt tgtggctat taaattaatt tataccat

gtaat taaaacaccagt tatctatagataatat t tataaggtgat taat tat

atatt tggaaaggacaaaatgtggataaacagtaagt tgaat t tgat tagaacaggc

ttcttactttgctctaggatctacataactgaagcaatacactattagttgetg

acaattaaaatgtagcctaatgtttettgattccctgaaatcatt tcgatggta

catgtaatgtcagtatt tetgaggttct ccaatt tgatggaactgcagtcatcaata

tgat atgatatatgaatat tatgcetct tacatt catccatct tcgatatat tetata

gctgtaatat tcaatgctgcaaaacgatgatgtctggat tgect taaaaataact

gatgcgacggttaatag

B.
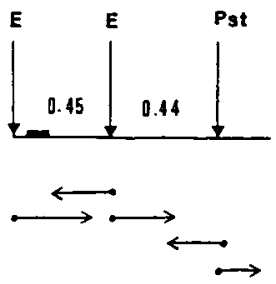

$-61$

$-1$

54

FIG. 5. A. - Upstream sequence of the rabbit $\alpha_{s}$-casein gene and the first intron. Sequence analysis was carried out according to the method of SANGER et al. (1977) using $\left[\alpha_{-}{ }^{35} \mathrm{~s}\right]-\mathrm{dATP}$ as marker and $0.2 \mathrm{~mm}$ thick gels run in an LKB apparatus. Underlined sequences are detailed in fig. 8, 9, 10 and 11 .

Exon sequences are shown in upper case letters.

B. - Strategy of sequencing. Exons are represented by solid boxes. 


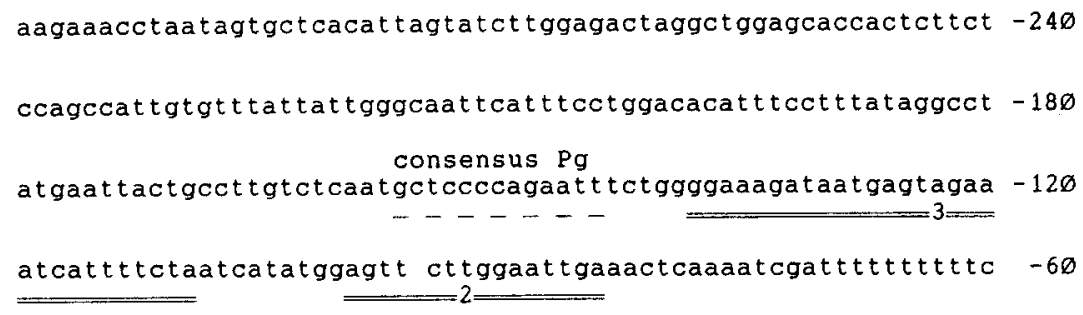

FIG. 6. - Upstream sequence of the rabbit $\beta$-casein gene and the first exon. (See legend of fig. 5).

showed a typical TATA consensus sequence (Breathnach et Chambon, 1981) whereas both $\alpha_{\mathrm{s} 1}$-casein and WAP had the sequence in a modified form. Interestingly, this somewhat unusual TTTAAAT sequence has been found in most of the milk protein genes so far studied (Campbell et Rosen, 1984 ; Yu-Lee et al., 1986). Moreover, an additional TATA box located $53 \mathrm{bp}$ upstream from the first TATA box was found in rabbit $\alpha_{\mathrm{s} 1}$-casein gene. It is striking that this fact was also mentioned for bovine $\alpha_{\mathrm{s} 1}$-casein gene which gives rise to the formation of a minor $\alpha_{\mathrm{s} 1}$-casein mRNA starting from position $-35 \mathrm{bp}(\mathrm{Yu}$-Lee et al., 1986). In addition, the rabbit $\beta$-casein gene contains the ATTAAATGCA sequence upstream from the classical TATA box. This sequence is reminescent of that found upstream from the WAP gene TTTAAATGCA. This sequence in the $\beta$-casein gene might be, as for $\alpha_{\mathrm{s} 1}$-casein gene, a second functional TATA box.

The CAAT box present in many other eucaryotic genes (Breathnach and Chambon, 1981) could not be determined in any of the three genes. Glucocorticoid receptors are known to stimulate their target genes by interacting with a sequence found on the upstream region of these genes (Hutchinson et al., 1986). The nonanucleotide consensus sequence which binds glucocorticoid receptor has not been found yet in any of the three rabbit milk protein genes. However, the hexanucleotide sequence AGGAAG (Hall et al., 1987) was repeated five times (with two of them in the opposite direction) in the upstream part of the rabbit WAP gene. These sequences possibly take part in the regulation of WAP gene transcription. However, experiments not depicted here have shown that, although glucocorticoids exert a strong effect on $\beta$-casein mRNA accumulation (fig. 1), their stimulation is rather slow, suggesting that their action might not be mediated through direct binding of glucocorticoid receptor to milk protein genes.

In rabbit $\beta$-casein gene, at position $-146 \mathrm{bp}$, a sequence of 14 nucleotides shares a $86 \%$ homology with the chicken sequence which has been shown to 
agatcttgtgctcgct $-18 \emptyset 1$

cgctctctcgctctctctctctctccttctgtctctctggaacttgecttcaaataaa-1741 taaataatt tet taaagactactgtttgttttt tatt tact taaagcagagtaac- 1681 agagaaagaaatacat tccgt t $t$ gctggt tcactccccaaatggccgctagatccagggc-162 1 taggccaggctgaagccagaacccetacctgggtctcccacgtgagt gacaggggcccaa-1561 gcacctgggccaaccacctctgct t cccagggacat tggcagggagatgggtcaggagc-1501 agagcagccagaactcaggctgccctccaatctgagacatcagct t tgcaagtggtagct -1441 taacccacgtgtcacccagccccaagat tcatgt taatgataggaaat t taat t tat $t-1381$ tgctcagat tgaaacat ta taagggcaccacaataagcagagt ccagagatgagagaaaa-1321 acaaaaataaataaaaaatct tgtatt tcggt tccttgcaggcactttct tcect -1261 tgtggaacaaggagcccaaaaaccgcagcagggggcccagtggaga tgggagatgcctgg- $12 \emptyset 1$ gaagaacaccetgggaggagct ccgggaggcgcaggaggagggggt tcctgacggggtca-1141 gctctggcet cgggcccagcaccccagtgagaaggatgggagccgcccagcccagcetgg-1ø8 1 ctcgggcaggaaggggcaggcccaaccacagccectctgctcct tcgcagggagcggaac- $1 \emptyset 21$ agcccacggaagcatctt cggact tagagcegtgaacetcgccacgcegtgtccagccc - 961 actgtctgagagccetcactggccagtccaggcccaggcccaggactctgtgggcagctg -901 cagggctggaacagagt tacccgagcctggggetgcgaggggtgcctttgtggaacccac -841 aaaggacgct t tgtggaaggacatt tggggctggagcctccccacggcacagcctgaggc -781 ccaggaagctgcgaggagctctgtgectgaggccggagcagggtcgetggetggacaggg -721 ctgtggcccccagccatcctgccetggggtctccgcagtccccatggccecttcectgtc -661 

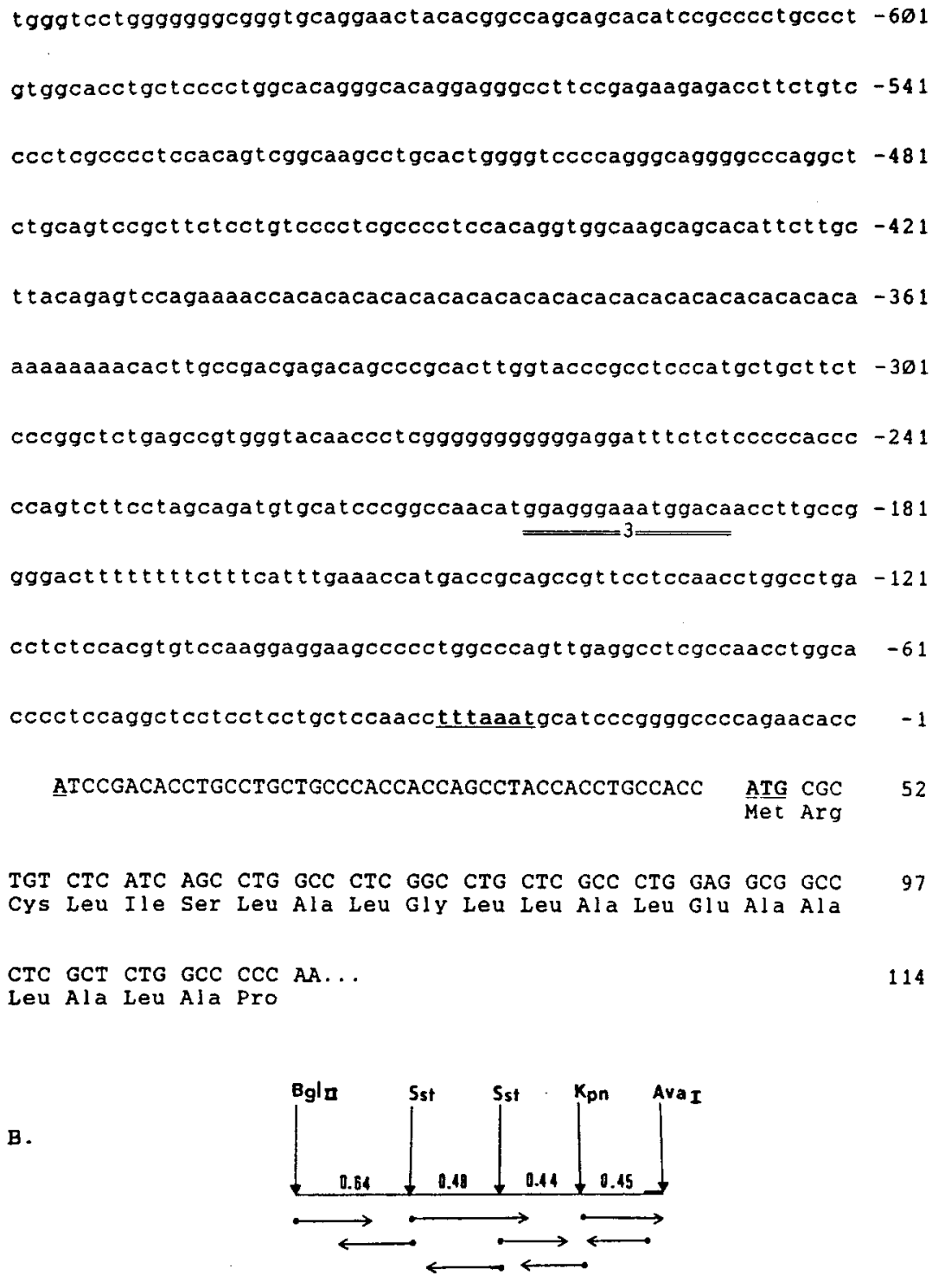

B.

FIG. 7. A. - Upstream sequence of the rabbit WAP gene and the first exon. (See legend of fig. 5). B. - Strategy of sequencing. 
interact with progesterone receptor in chicken ovalbumin gene (Compton et al., 1983). However, the functional significance of this sequence is quite uncertain. Indeed, ovalbumin gene is stimulated by progesterone whereas milk protein genes are inhibited by this steroid. Further, recent experiments have demonstrated that the DNA sequence of the rabbit uteroglobin gene, which binds progesterone receptor, is quite different from that proposed for chicken ovalbumin gene (Bailly et al., 1986). This rabbit uteroglobin sequence was not found in the upstream regions of the rabbit milk protein genes so far examined.

3) Sequence homologies of the different genes. - Apart from the TATA box, a short sequence of seven nucleotides was similar downstream from the TATA sequence in the WAP and the $\beta$-casein, but not in the $\alpha_{\mathrm{s} 1}$-casein gene (fig. 8).

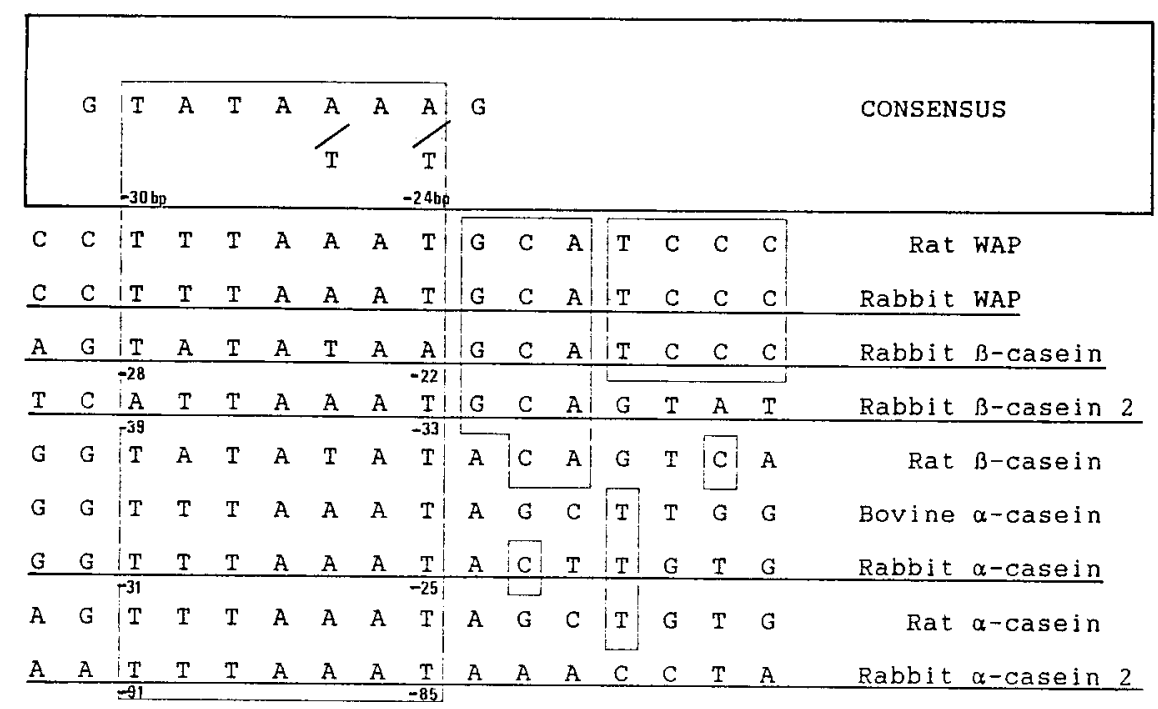

FIG. 8. - Sequence homology between milk protein genes from various species in the region of the TATA box. Comparison of sequences was carried out according to the method proposed by Kanehisha (1984).

Recently, it has been proposed that a conserved sequence might be present in the regulatory regions of all the milk protein genes (Hall et al., 1987). This sequence has been found in human $\alpha$-lactalbumin gene and in several casein genes from guinea-pig and rat (Qasba et Safaya, 1984). An analogous sequence was also found in the upstream region of the rabbit $\beta$-casein gene (fig. 9). The same sequence, or at least a part of it, was also present in the rabbit WAP gene (fig. 9). Sequencing in progress will soon reveal if this consensus sequence is also present in the rabbit $\alpha_{\mathrm{s} 1}$-casein gene. 


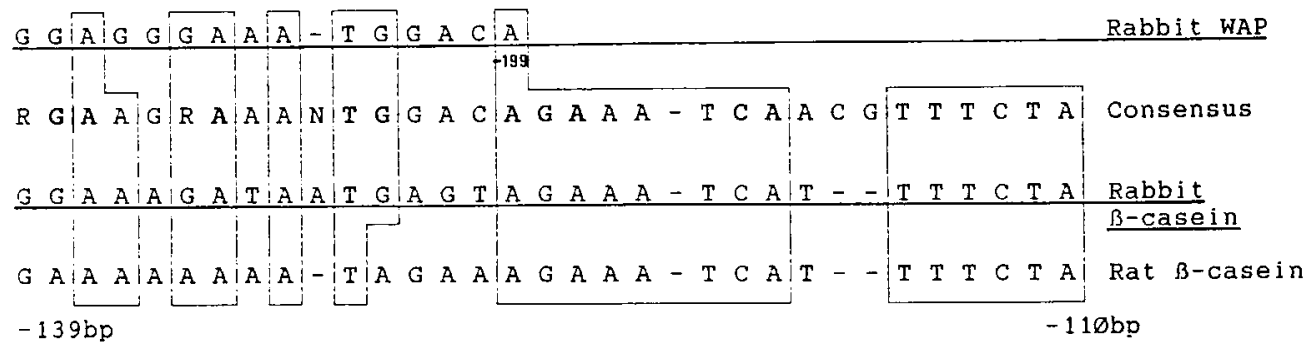

FIG. 9. - Sequence homology of a region of the three rabbit genes with the consensus sequence defined by Hall et al. (1987).

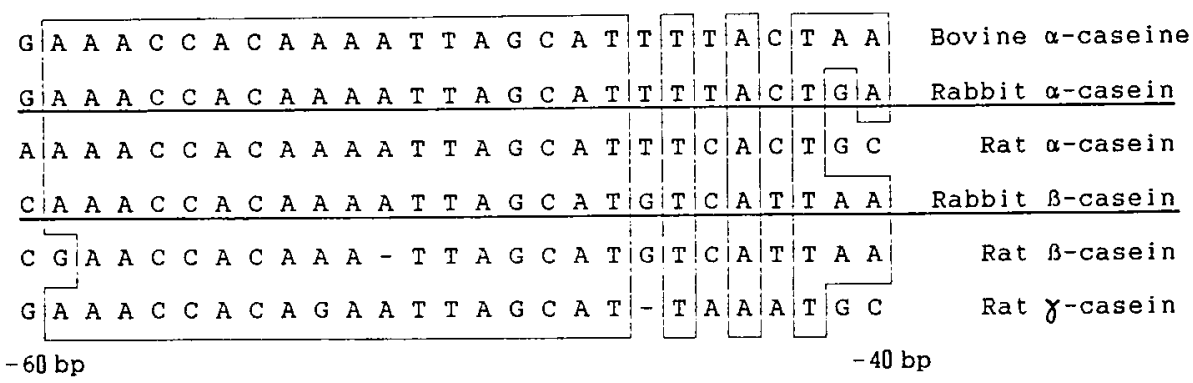

FIG. 10. - Sequence homology between milk protein genes from various species in the upstream region of the TATA box.

A highly conserved stretch of DNA, located in the $-60 \mathrm{bp}-40 \mathrm{bp}$ region of several rat (Jones et al., 1985 ; Yu-Lee and Rosen, 1983; Yu-Lee et al., 1986) and bovine casein genes was also found in rabbit $\alpha$ and $\beta$-casein genes (fig. 10).

Another conserved DNA fragment was present $25 \mathrm{bp}$ upstream from the previous one (fig. 11).

It is tempting to imagine that these sequences of DNA are involved in the hormonal control of milk protein gene expression. To the best of our knowledge, this has not been demonstrated yet.

III. The cellular mechanism possibly involved in the transduction of the prolactin message to milk protein genes.

1) Role of kinase $C$. - Kinase $C$ has been shown to be involved in the transmission of hormonal messages and phorbol esters strongly stimulate this enzyme like natural diacylglycerol (Nishizuka, 1986). In a previous work, we 


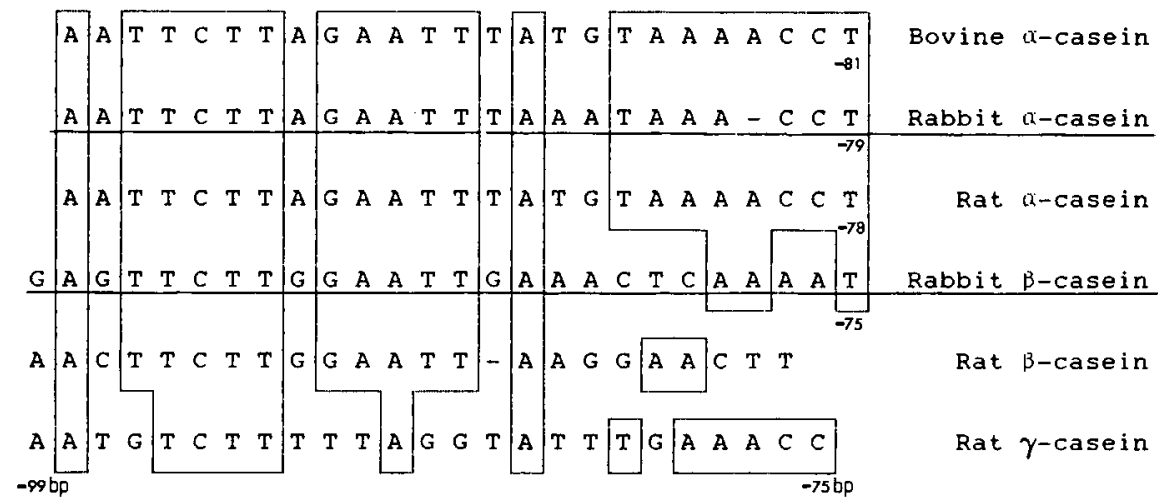

FIG. 11. - Sequence homology between milk protein genes from various species in the -100 to -75 bp region.

\section{TABLE 1}

Effect of phorbol esters and kinase $C$ inhibitors on the induction of $\beta$-casein gene expression by prolactin.

Mammary explants were cultured for two days in the presence of insulin and cortisol $(1+C)$. The agents and prolactin (PRL) were then added. After $8 \mathrm{~h}$, tissue was collected and frozen. The presence of $\beta$-casein mRNA was evaluated using the corresponding oligolabelled DNA fragment as probe. Results which are means of triplicates are expressed as cpm of probe hybridized to filters loaded with $25 \mu \mathrm{g}$ total RNA. (PdiBu: phorbol-12,13-dibutyrate, DPA : phorbol-12,13 diacetate, TPA : 12-0tetradecanoylphorbol-13-acetate).

\begin{tabular}{|c|c|c|c|c|}
\hline \multirow{2}{*}{$\begin{array}{c}\text { Hormones } \\
\text { Agents }\end{array}$} & \multicolumn{2}{|c|}{$1+C$} & \multicolumn{2}{|c|}{$I+C+P R L$} \\
\hline & - & + & - & + \\
\hline PdiBu $(100 \mathrm{ng} / \mathrm{ml})$ & 141 & - & 980 & 126 \\
\hline PDA $(100 \mathrm{ng} / \mathrm{ml})$ & 141 & - & 980 & 635 \\
\hline TPA $(100 \mathrm{ng} / \mathrm{ml})$ & 141 & - & 980 & 1042 \\
\hline $\mathrm{H} 7(50 \mu \mathrm{M})$ & 141 & - & 980 & 1415 \\
\hline W7 $(50 \mu \mathrm{M})$ & 141 & - & 980 & 1439 \\
\hline$\underset{(100 \mathrm{ng} / \mathrm{ml})}{P \mathrm{diBu}}+\underset{(50 \mu \mathrm{M})}{\mathrm{H7}}$ & 141 & - & 980 & 93 \\
\hline$\underset{(100 \mathrm{ng} / \mathrm{mg})}{\mathrm{PdiBu}}+\underset{(50 \mu \mathrm{M})}{\text { W7 }}$ & 141 & - & 980 & 89 \\
\hline Amiloride $(250 \mu \mathrm{M})$ & 100 & 266 & 697 & 702 \\
\hline Gossipol $(100 \mu \mathrm{M})$ & 100 & - & 697 & 842 \\
\hline
\end{tabular}

observed that phorbol $-12,13$ dibutyrate (PdiBu) and, to a lower degree, 12-O-tetradecanoylphorbol -13-acetate (TPA) inhibited the differentiation of mammary cell by prolactin (Martel et al., 1983a). Recent investigations have shown that in many tissues, kinase $\mathrm{C}$ is progressively down-regulated by phorbol esters or diacylglycerol. This problem was reassessed in the cultured mammary gland, with induction times not longer than $8 \mathrm{~h}$.

Results of table 1 indicate that PdiBu was a strong inhibitor of prolactin action whereas at the same concentration $(100 \mathrm{ng} / \mathrm{ml})$ TPA, a strong tumor 

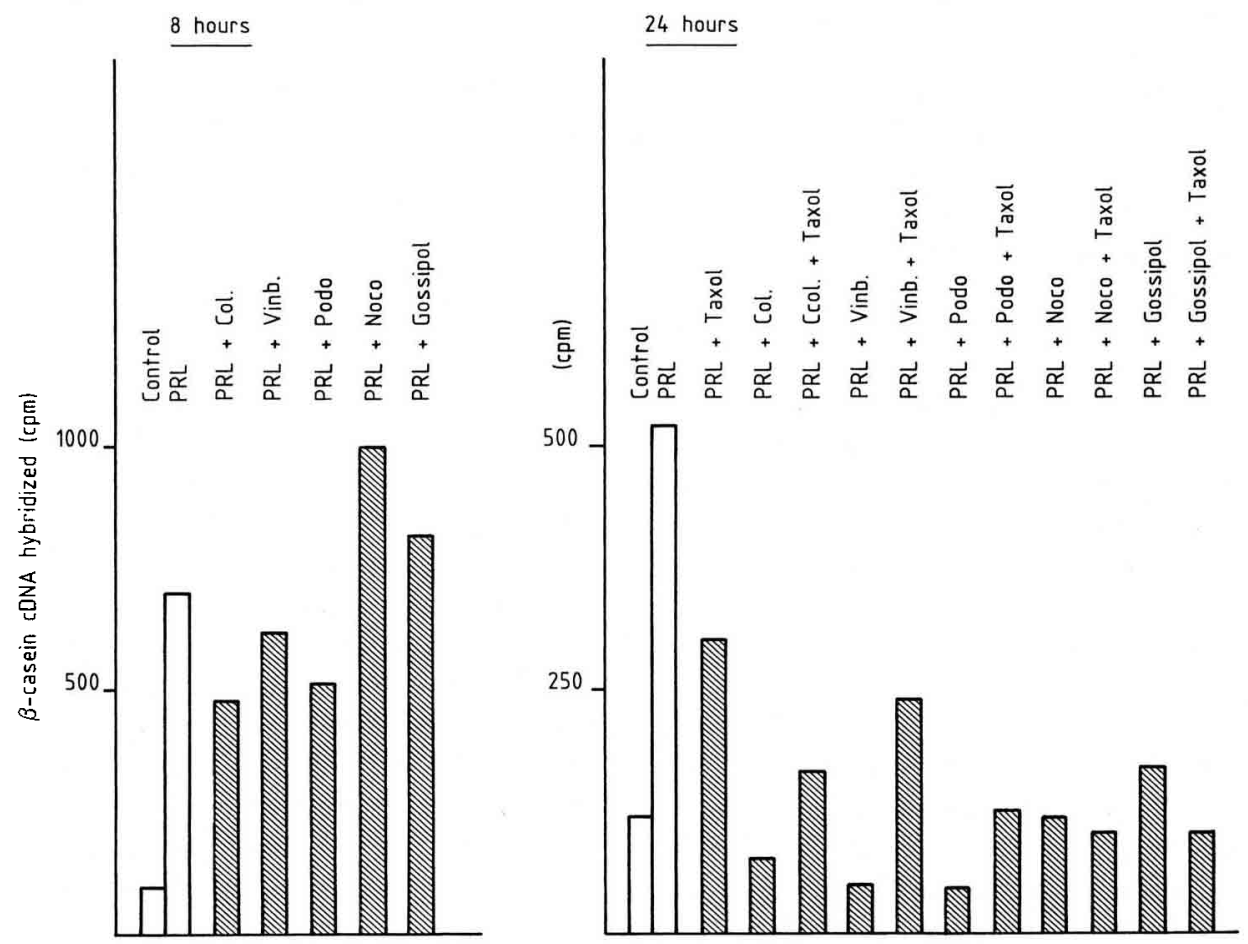

FIG. 12. - Effect of various microtubule inhibitors and taxol on the induction of $\beta$-casein $m R N A$ accumulation. Mammary explants were cultured for two days in the presence of insulin $(5 \mu \mathrm{g} / \mathrm{ml})$ and cortisol $(500 \mathrm{ng} / \mathrm{ml})$. Prolactin $(1 \mu \mathrm{g} / \mathrm{ml})$ with or without drugs was then added and the culture was pursued 8 hours in one culture and 24 hours in the other. $\beta$-casein mRNA in the total RNA of the explants was then measured with a specific cDNA probe as depicted in fig. 1.

Colchicine (col), vinblastine (vinb) and podophylotoxin (podo) were present at a concentration of $1 \mu \mathrm{M}$. The concentration of nocodazole (noco) and gossipol was $10 \mu \mathrm{M}$ and that of taxol was $25 \mu \mathrm{M}$.

promoter, was inactive and PDA, an analogue devoid of promoter activity, was slightly inhibitory. The specific inhibitor of kinase $\mathrm{C}, \mathrm{H}_{7}$ (Hidaka et al., 1984), did not inhibit prolactin action and did not abrogate the inhibitory effect of PdiBu. Data not shown here also indicate that similar conclusions can be drawn when induction is limited to $3 \mathrm{~h}$. On the other hand; parallel measurements of actin mRNA in the same samples revealed that no modification of this mRNA occurred under PdiBu and TPA action whereas PDA was slightly inhibitory (not shown). PdiBu therefore did not act through a general cytotoxic effect. Association of the calcium ionophore A23187 to phorbol esters did not change these conclusions (not shown). The compound $W_{7}$, which is a strong calmodulin inhibitor and a weak kinase $C$ inhibitor (Hidaka et al., 1984), did not prevent prolactin action. Similarly, amiloride which is an inhibitor of kinase C (Besterman et al., 1985), did not prevent $\beta$-casein mRNA from accumulating under prolactin stimulation after $8 \mathrm{~h}$ (table 1). (In longer cultures, amiloride inhibits prolactin actions). In the same 
way, gossipol, another kinase C inhibitor (Etindi and Rillema, 1987), inhibited prolactin action only after a long culture period (table 1 and figure 12). These data, indicating that there is no clear correlation between the activity of kinase $C$ and the stimulation of casein gene expression, are in agreement with a recent report which shows that, in mouse mammary gland, kinase $C$ is at its lowest level during lactation (Caufield and Bolander, 1986). The inhibitory effect of PdiBu is therefore most likely not due to genuine phorbol ester action. It might be due to the presence of the butyrate moiety which is a strong inhibitor of prolactin action (Martel et al., 1983b).

2) Role of phospholipid derivatives. - Recent works carried out in various biological systems have pointed out the role of phospholipid derivatives and particularly of inositol triphosphate on the transduction of hormonal messages (Majerus et al., 1986). Several inhibitors have been shown to block the cycle generating phosphatidylinositol. One of these inhibitors is neomycin which competes with phosphatidylinositol in its hydrolysis by phospholipase $C$ (Carney et al., 1985). Neomycin added with prolactin at a concentration of $1 \mathrm{mM}$ inhibited strongly the hormonal action (table 2 ). Although neomycin acts on phospholipase $C$ it is known to have other effects also related with phospholipid metabolism (Polascik et al., 1987 ; Nakashima et al., 1987). The experiment with neomycin thus does not strictly demonstrate that hydrolysis of phosphatidylinositol is required in prolactin action. Hexachlorocyclohexane has also been demonstrated to prevent phospholipase $\mathrm{C}$ from hydrolysing phosphatidylinositol (Ristow et al., 1980; Hoffmann et al., 1980). This compound was unable to alter prolactin action (table 2). LiCl prevents the recycling of inositol phosphate into phosphatidylinositol (Berridge, 1983). LiCl added with prolactin did not affect the induction of $\beta$-casein gene expression (table 2). The interpretation of the experiment with $\mathrm{LiCl}$ may be complicated by the fact that free inositol was present in medium 199 used in the cultures. In these conditions, recycling of inositol phosphate may be unnecessary for phosphatidylinositol phosphate to be regenerated (Ishihara et al., 1987). Quercetin, which is an inhibitor of several kinases including phosphatidylinositol kinase (Sharoni et al., 1986), kinase C (Gschwendt et al., 1983) and a kinase found in mammary gland (Levy et al., 1984) did not prevent prolactin from trigerring the accumulation of $\beta$-casein mRNA (table 2 ). Phosphatidic acid is a compound generated after hydrolysis of phospholipids by phospholipase $\mathrm{C}$ and it is a precursor of phospholipids. When added to culture medium, phosphatidic acid has been shown to mimic growth factor action for the accumulation of c-myc mRNA (Moolenaar et al., 1986). When added with or without prolactin, phosphatidic acid did not mimic or alter hormonal response (table 2). Two other derivatives of phospholipid, phosphoethanolamine (table 2) and phosphocholine, were unable to mimic prolactin action (not shown). All these data argue rather in favour of the idea that phosphatidylinositides are not strictly involved in the mechanism of prolactin action. Obviously, additional experiments have to be performed before this possibility can be totally ruled out.

3) Role of tyrosine kinase. - Tyrosine kinase activity is associated with the receptor of several protein hormones and, in the case of insulin, it is involved in 
TABLE 2

Effect of various agents related to phospholipid metabolism on the induction of $\beta$-casein gene expression by prolactin. Conditions of culture are those described in table 1 . Results which are means of triplicates are expressed as cpm of $\beta$-casein cDNA probe hybridized to filters loaded with $25 \mu \mathrm{g}$ total RNA.

\begin{tabular}{lcccc}
\hline Hormones & \multicolumn{2}{c}{$\mathrm{I}+\mathrm{C}$} & \multicolumn{2}{c}{$\mathrm{I}+\mathrm{C}+\mathrm{PRL}$} \\
\hline \multicolumn{1}{c}{ Agents } & - & + & - & + \\
\hline Neomycine $(1 \mathrm{mM})$ & 126 & - & 772 & 218 \\
LiCl $(20 \mathrm{mM})$ & 126 & 165 & 772 & 800 \\
Hexachlorocyclohexane $(30 \mu \mathrm{g} / \mathrm{ml})$ & 141 & 75 & 980 & 1151 \\
Quercetin $(100 \mu \mathrm{M})$ & 126 & 154 & 772 & 936 \\
Phosphatidic acid $(100 \mu \mathrm{M})$ & 141 & 160 & 980 & 1136 \\
Phosphoethanolamine $(10 \mathrm{mM})$ & 100 & 140 & 980 & - \\
\hline
\end{tabular}

TABLE 3

Effects of various agents interfering with phosphory/ation on the induction of casein gene expression by prolactin. Conditions of culture are described in table 1 . Results which are means of triplicates are expressed as cpm of $\beta$-casein probe hybridized to filters loaded with $25 \mu \mathrm{g}$ total RNA.

\begin{tabular}{|c|c|c|c|c|}
\hline \multirow[t]{2}{*}{ Hormones } & \multicolumn{2}{|c|}{$1+C$} & \multicolumn{2}{|c|}{$I+C+P R L$} \\
\hline & - & + & - & + \\
\hline Sodium orthovanadate $(50 \mu \mathrm{M})$ & 126 & 168 & 772 & 364 \\
\hline $\begin{array}{l}5^{\prime} P \text {-fluorosulfonyl } \\
\text { benzoyl adenosine }(100 \mu \mathrm{M})\end{array}$ & 126 & 140 & 772 & 631 \\
\hline
\end{tabular}

the transmission of the hormonal message to glucose carrier (Ellis et al., 1987). Tyrosine kinase activity is inhibited by $5^{\prime}$-p-fluorosulfonylbenzoyladenosine (Buhrow et al., 1982), amiloride (Davis and Czech, 1985) and quercetin (Levy et al., 1984). None of these compounds prevented prolactin action (table 2 and 3 ). On the other hand, sodium orthovanadate, which has been shown to mimic hormone action by specifically inhibiting tyrosine phosphatase (Klarlund, 1985 ; Green, 1986), did not mimic or stimulate prolactin action. On the contrary, it inhibited partly the accumulation of casein mRNA (table 3 ). These data support the view that a tyrosine phosphorylation is not necessary for prolactin to activate casein gene expression.

4) Role of microtubules and tubulin. - Previous works have shown that several tubulin binding drugs (colchicine, vinblastine, podophyllotoxin, nocodazole and tubulozole $\mathrm{C}$ ) inhibit the induction of casein synthesis by prolactin (Servely et al., 1987). One possible interpretation of these data was that microtubules are involved in the transmission of the prolactin message. More recently, it has been observed that estramustine, a microtubule-disrupting drug 
which binds MAP but not tubulin, is unable to inhibit prolactin action (Zwierzchowski et al., 1988). These experiments indicate that free tubulin, rather than tubulin organized in microtubules, is implicated in the prolactin mechanism of action. Results presented in figure 12 indicate that after 8 hours of action, the various microtubule-disrupting drugs, at most, only partially inhibited prolactin action, although in these conditions they rapidly disorganize the microtubular network (Ollivier-Bousquet, 1979). Taxol which is known to bind tubulin and to prevent disruption of microtobules by some of the drugs (Schiff and Horwitz, 1981) was slightly inhibitory for prolactin action and did not overcome the action of the drugs in all cases (fig. 12). The microtubule-disrupting drugs used here and taxol bind to specific sites on tubulin (Parness and Horwitz, 1981). The fact that taxol partially restores prolactin action in some cases might be due to some modifications of tubulin conformation independently of microtubule formation. These data provide additional support to the idea that microtubule integrity is not required for prolactin to act and that free tubulin rather than the microtubules themselves are involved in the transduction of the prolactin message.

\section{Conclusion.}

The data reported here indicate that three major rabbit milk protein genes, $\alpha_{\mathrm{s} 1}$-casein, $\beta$-casein and WAP genes, are regulated by essentially similar hormonal control. The determination of the DNA structure in the upstream regions of the genes suggests that the conserved sequences are involved in the control of their transcription. The introduction, into cultured cells and into mouse and rabbit embryos, of hybrid genes containing these sequences has been undertaken tentatively to define the regulatory DNA sequences. These experiments and those aimed at determining the structure of the prolactin receptor should contribute to the understanding of the mechanism of prolactin action which still remains an enigma.

Recu en octobre 1987 Accepté en avril 1988.

Acknowledgments. - The technical help of Mrs C. Puissant and M. L. Fontaine is fully acknowledged.

This work has been carried out with the financial help of the ATP "Hormones hypophysaires et fonction de reproduction chez les Vertébrés" (I.N.R.A.) and the Biotechnology Action Program of the European Community.

Résumé. Données récentes concernant le mécanisme de la régulation hormonale de l'expression des gènes des protéines du lait chez la lapine; étude de la structure de ces gènes.

Des explants et des cellules isolées de glande mammaire de lapin ont été cultivés en présence d'insuline, de prolactine et de cortisol seuls ou associés. Le contenu cellulaire en ARNm de la caséine $-\alpha_{s 1}$, de la caséine- $\beta$ et de la whey acidic protein (WAP) a été évalué en utilisant les sondes ADNc correspondantes. Dans tous les cas, I'ARNm de la caséine- $\alpha_{\mathrm{s} 1}$ 
est le plus abondant et celui de la WAP le moins abondant. Les trois gènes présentent pour l'essentiel une dépendance semblable vis-à-vis des hormones. La prolactine stimule l'accumulation des trois ARNm et l'insuline et le cortisol amplifient cette stimulation. Des fragments d'ADN génomique de lapin insérés dans le phage $\lambda$ et contenant les séquences des gènes de la caséine- $\alpha_{\mathrm{s} 1}$, de la caséine- $\beta$ et de la WAP ont été clonés. La séquence primaire de ces gènes au voisinage du site CAP a été établie. Une comparaison des séquences situées en amont des sites CAP fait apparaître des analogies frappantes avec les gènes homologues de vache, de rat et de cobaye. Ceci suggère que ces séquences participent au contrôle transcriptionnel des gènes par les hormones. Le mécanisme impliqué dans la transduction du message prolactinique aux gènes des protéines du lait est inconnu. Avec l'aide des cultures d'explants mammaires, plusieurs mécanismes classiques de transduction ont été examinés. L'ester de phorbol, phorbol-12,-13-dibutyrate (PdiBu) inhibe l'action de la prolactine. Cependant, un autre promoteur de tumeur, le 12-Otetradecanoyl phorbol-13-acétate (TPA) ne modifie pas l'action de la prolactine. L'inhibiteur $\mathrm{H} 7$ de la kinase $\mathrm{C}$ ne s'oppose pas à l'action de la prolactine et il ne lève pas l'inhibition du PdiBu. La kinase $\mathrm{C}$ n'est donc probablement pas essentielle pour que la transduction du message prolactinique aux gènes des protéines du lait ait lieu. La néomycine qui inhibe l'hydrolyse du phosphatidyl inositol par la phospholipase $C$ empêche la prolactine d'agir, tandis que d'autres inhibiteurs restent sans effet. La dégradation du phosphatidyl inositol n'est probablement pas une étape essentielle dans l'action de la prolactine sur les gènes des protéines du lait. Des inhibiteurs de la tyrosine kinase et de la phosphatase ne modifient que modestement l'action de la prolactine. Les mécanismes de transduction utilisant l'activité tyrosine kinase ne sont donc probablement pas impliqués dans la transduction du message prolactinique à ses gènes cibles.

\section{References}

ANDRES A. C., SCHONENBERGER C. A., GRONER B., HENNIGHAUSEN L., LEMEUR M., GERLINGER P., 1987. Ha-ras oncogene expression directed by a milk protein gene promoter : tissue specificity, hormonal regulation, and tumor induction in transgenic mice. Proc. nat. Acad. Sci., 84, 1299-1303.

BAILLY A., LE PAGE C., RAUCH M., MILGROM E., 1986. Sequence-specific DNA binding of the progesterone receptor to the uteroglobin gene: effects of hormone, antihormone and receptor phosphorylation. EMBO J., 5, 3235-3241

BERRIDGE M. J., 1983. Rapid accumulation of inositol triphosphate reveals that antagonists hydrolyse polyphosphoinositides instead of phosphatidyl inositol. Biochem. J., 212. 849-858.

BESTERMAN J. M., STRAFORD MAY W., LEVINE H., CRAGOE E. J., CUATRECASAS, 1985 . Amiloride inhibits phorbol ester-stimulated $\mathrm{Na}^{+} / \mathrm{H}^{+}$exchange and protein kinase C. J. biol. Chem., 260, 1155-1159.

BREATHNACH R., CHAMBON P., 1981. Organization and expression of eucaryotic split genes coding for proteins. Ann. Rev. Biochem., 50, 349-383.

BUHROW S. A., COHEN S., STAROS J. V., 1982. Affinity labeling of the protein kinase associated with the epidermal growth factor receptor in membrane vesicles from A431 cells. J. biol. Chem., 257, 4019-4022.

CAMPBELL S. M., ROSEN J. M., 1984. Comparison of the whey acidic protein genes of the rat and mouse. Nucl. Ac. Res., 12, 8685-8697.

CARNEY D. H., SCOTT D. L., GORDON E. A., LABELLE E. F., 1985. Phophoinositides in mitogenesis : neomycin inhibits Thrombin-stimulated phosphoinositide turnover and initiation of cell proliferation. Cell, 42, 479-488.

CAUFIELD J. J., BOLANDER F. F., 1986. Involvement of protein kinase $C$ in mouse mammary gland. J. Endocr., 109, 29-34.

CHOMCZYNSKI P., QASBA P., TOPPER Y. J., 1984. Essential role of insulin in transcription of the rat 25000 molecular weight casein gene. Science, 226, 1326-1328. 
CHOMCZYNSKI P., QASBA P., TOPPER Y. J., 1986. Transcriptional and post-transcriptional roles of glucocorticoid in the expression of the rat 25000 molecular weight casein gene. Biochim. Biophys. Res. Com., 134, 812-818.

COMPTON J. G., SCHRADER W. T., O'MALLEY B. W., 1983. DNA sequence preference of the progesterone receptor. Proc. nat. Acad. Sci. U.S.A., 80, 16-20.

DAVIS R. J., CZECH M. P., 1985. Amiloride directly inhibits growth factor receptor tyrosine kinase activity. J. biol. Chem., 260, 2543-2551

DJIANE J., DUSANTER-FOURT I., KATOH M., KELLY P. A., 1985. Biological activities of binding site specific monoclonal antibodies to prolactin receptors of rabbit mammary gland. J. biol. Chem., 260, 11430-11435.

DJIANE J., HOUDEBINE L. A., KELLY P. A., 1981. Prolactin-like activity of anti-prolactin receptor antibodies on casein and DNA synthesis in the mammary gland. Proc. nat. Acad. Sci., U.S.A., 78, 7445-7448.

ELLIS L., MORGAN D. O., CLAUSER E., ROTH R. A., RUTTER W. J., 1987. A membrane-anchored cytoplasmic domain of the human insulin receptor mediates a constitutively elevated insulin-independent uptake of 2-deoxyglucose. Mol. Endocr., 1, 15-24.

ETINDI R. N., RILLEMA T. A., 1987. Effect of a kinase C inhibitor, gossypol, on the actions of prolactin in cultured mouse mammary tissues. Biochim. Biophys. Acta, 927, 345-349.

FLAIM K. E., HUTSON S. M., LLOYD C. E., TAYLOR J. M., SHIMAN R., JEFFERSON L. S., 1985. Direct effect of insulin on albumin gene expression in primary cultures of rat hepatocytes. Am. J. Physiol., 249, E447-E453.

GANGULY R., METHA N. M., GANGULY N., BANERJEE M. R., 1979. Glucocorticoid modulation of casein gene transcription in the mouse mammary gland. Proc. nat. Acad. Sci., U.S.A., 76, $6466-6470$.

GORDON K., LEE E., VITALE J. A., SMITH A. E., WEST PHAL H., HENNIGHAUSEN L., 1987. Production of human tissue plasminogen activator in transgenic mouse milk. Biotechnology, 5, 1183-1187.

GREEN A., 1986. The insulin-like effect of sodium vanadate on adipocyte glucose transport is mediated at a post-insulin receptor level. Biochem. J., 238, 663-669.

GROSCLAUDE F., JOURDRIER P., MAHE M. F., 1978. Polymorphisme de la caséine- $\alpha_{\mathrm{s} 2}$. Ann. Génét. Sél. anim., 10, 313-320.

GUYETTE W. A., MATUSIK R. J., ROSEN J. M., 1979. Prolactin-mediated transcriptional and post-transcriptional control of casein gene expression. Cell, 17, 1013-1019.

GSCHWENDT M., HORN F., KITTSTEIN W., MARKS F., 1983. Inhibition of the calcium - and phospholipid - dependent protein kinase activity from mouse brain cytosol by quercetin. Biochem. Biophys. Res. Comm., 117, 444-447.

HALL L., EMERY D. C., DAVIES M. S., PARKER D., CRAIG R. K., $1987 . \quad$ Organization and sequence of the human $\alpha$-lactalbumine gene. Biochem. J., 242, 735-742.

HIDAKA H., INAGAKI M., KAWAMOTO S., SASAKI Y., 1984. Isoquinoline sulfonamides, novel and potent inhibitors of cyclic nucleotide dependent protein kinase and protein kinase $\mathrm{C}$. Biochemistry, 23, 5031-5041.

HOFFMANN R., ERZBERGER P., FRANKS W., RISTOW H. J., 1980. Increased phosphatidyl-inositol synthesis in rat embryo fibroblasts after growth stimulation and its inhibition by $\delta$-hexachlorocyclohexane. Biochim. Biophys. Acta, 618, 282-292.

HOUDEBINE L. A., 1977. $\alpha_{\mathrm{s} 1}$ and $\beta$-casein gene frequencies in ewe and cow genome. Biochimie, 59, 659-660.

HOUDEBINE L. A., DEVINOY E., DELOUIS C., 1978. Stabilization of casein mRNA by prolactin and glucocorticoids. Biochimie, 60, 57-63.

HOUDEBINE L. A., DJIANE J., DUSANTER-FOURT I., MARTEL P., KELLY P. A., DEVINOY E., SERVELY J. L., 1985. Hormonal action controlling mammary activity. J. Dairy Sci., 68, 489-500.

HUTCHINSON C. A., NORDEEN S. K., VOGT K., EDGELL M. H., 1986. A complete library of point subtitution mutations in the glucocorticoid response element of mouse mammary tumor virus. Proc. nat. Acad. Sci, U.S.A., 83, 710-714. 
ISHIHARA M., FEDARKO N. S., CONRAD H. E., 1987. Involvement of phosphatidylinositol and insulin in the coordinate regulation of proteoheparan sulfate metabolism and hepatocyte growth. J. biol. Chem., 262, 4708-4716.

JONES W. K., YU-LEE L. Y., CLIFT S. M., BROWN T. L., ROSEN J. M., 1985 . The rat casein multigene family: fine structure and evolution of the $\beta$-casein gene. J. biol. chem., 260 , $7042-7050$.

KANEHISHA M. I., 1984. Use of statistical criteria for screening potential homologies in nucleic acid sequences. Nucl. Ac. Res., 12, 203-213.

KLARLUND J. K., 1985. Transformation of cells by an inhibitor of phosphatase acting on phosphotyrosine in proteins. Cell, 41, 707-717

LEE K. L., ISHAM K. R., JOHNSON A., KENNEY F. T., 1986. Insulin enhances transcription of the tyrosine aminotransferase gene in rat liver. Arch. Biochim. Biophys., 248, 597-603.

LEE Y. H. P., LEE W. H., KAETZEL C. S., PARRY G., BISSEL M. J., 1985. Interaction of mouse mammary epithelial cells with collagen substrata : Regulation of casein gene expression and secretion. Proc. nat. Acad. Sci, U.S.A., 82, 1419-1923.

LEVY J., TEVERSTEIN I., MARBACH M., RADIAN S., SHARONI Y., 1984. Tyrosine protein kinase in the DMBA-induced rat mammary tumor : inhibition by quercetin. Biochem. Biophys. Res. Com., 123, 1227-1233.

MAJERUS P. W., CONNOLLY T. M., DECKMYN H., ROSS T. S., BROSS T. E., ISHII H., BANSAL V. S., WILSON D. B., 1986. The metabolism of phosphoinositide derived messenger molecules. Science, 234, 1519-1526.

MANIATIS T., 1978. Isolation of structural genes from libraries of eucaryotic DNA. Ce/l, 15. 687-701.

MANIATIS T., GOODBOURN S., FISCHER J.A., 1987. Regulation of inducible and tissue-specific gene expression. Science, 236, 1237-1244.

MARTEL P., HOUDEBINE L. A., TEYSSOT B., DJIANE J. 1983a. Effects of phorbol esters on multiplication and differenciation of mammary cells. Biol. Cell, 49, 119-126.

MARTEL P., HOUDEBINE L. A., TEYSSOT B., 1983b. Effect of sodium butyrate on the stimulation of casein gene expression by prolactin. FEBS Letters, 154, 55-59.

MOOLENAAR W. H., KRUIJER W., TILLY B. C., VERLAAN I., BIERMAN A. J., de LAAT S. W., 1986. Growth factor like action of phosphatidic acid. Nature, 323, 171-173.

NAKASHIMA S., TOHMATSU T., SHIRATO L., TAKENATA A., NOZAWA Y., 1987. Neomycin is a potent agent for arachidonic acid release in humal platelets. Biochem. Biophys. Res. Comm., 146, 820-826.

NISHIZUKA Y., 1986. Perspective on the role of protein kinase C stimulus-response coupling. J. nat Canc. Inst., 76, 363-370

OLLIVIER-BOUSOUET M., 1979. Effets de la cytocholasine B et de la colchicine sur l'action rapide de la prolactine dans la glande mammaire de lapine en lactation. Eur. J. Cell Biol., 19, 168-174.

PARNESS J., HORWITZ S. B., 1981. Taxol binds to polymerized tubulin in vitro. J. Ce/l Biol., 91, 479-487.

POLASCIK T., GODFREY P. P., WATSON S. P., 1987. Neomycin cannot be used as a selective inhibitor of inositol phospholipid hydrolysis in intact or semi-permeabilized human platelets. Biochem. J., 243, 815-819.

QASBA P. K., SAFAYA S. K., 1984. Similarity of the nucleotide sequences of rat $x$-lactalbumin and chicken lysozyme genes. Nature, 308, 377-380.

RISTOW H. J., METSMER T. O., WALTER S., PAUL D., 1980. Stimulation of DNA synthesis and myo-inositol incorporation in mammalian cells. J. Cell Physiol., 103, 263-269.

SANGER F., NICKEN S., COULSON A. R., 1977. DNA sequencing with chain termination inhibitors. Proc. nat. Acad. Sci., U.S.A., 74, 5463-5467.

SCHIFF P. B., HORWITZ S. B., 1981. Taxol assembles tubulin in the absence of exogenous guanosine 5' -triphosphate or microtubule-associated proteins. Biochemistry, 20, 3247-3252.

SERVELY J. L., GEUENS G. M. A., MARTEL P., HOUDEBINE L. A., DE BRABANDER M., 1987. Effect of tubulazole, a new synthetic microtubule inhibitor on the induction of casein gene expression by prolactin. Biol. Cell, 59, 121-128. 
SHARONI Y., TEVERSTEIN I., LEVY J., 1986. Phosphoinositide phosphorylation precedes growth in rat mammary tumors. Biochem. Biophys. Res. Comm., 13, 4876-4882.

SIMONS J. P., MCCLENAGHAN M., CLARK A. J., 1987. Alteration of the quality of milk by expression of sheep $\beta$-lactoglobulin in transgenic mice. Nature, 328, 530-532.

SUARD Y. M. L., TOSI M., KRAEHENBUHL J. P., 1982. Characterization of the translation products of the major mRNA species from rabbit lactating mammary glands and construction of bacterial recombinants. Biochem. J., 201, 81-90.

TEYSSOT B., HOUDEBINE L. M., 1980. Role of progesterone and glucocorticoids in the transcription of $\beta$-casein and ribosomal rRNA genes in the rabbit mammary gland. Eur. $J$. Biochem., 114, 597-608.

YU-LEE L. Y., RICHTER-MANN L., COUCH C. H., STEWART A. F., MACKINLAY A. G., ROSEN J. M., 1986. Evolution of the casein multigene family: conserved sequences in the $5^{\prime}$ flanking and exon regions. Nucl. Ac. Res., 14. 1883-1902.

YU-LEE L. Y., ROSEN J. M., 1983. The rat casein multigene family : I. fine structure of the $\gamma$-casein gene. J. biol. Chem., 258, 10794-10804.

ZWIERZCHOWSKI L., FLECHON J., OLLIVIER-BOUSQUET M., HOUDEBINE L. A., 1988. Effect of estramustine, a new antimicrotubule drug, on the induction of casein gene expression by prolactin. Biol. Cell, 61, 51-57. 